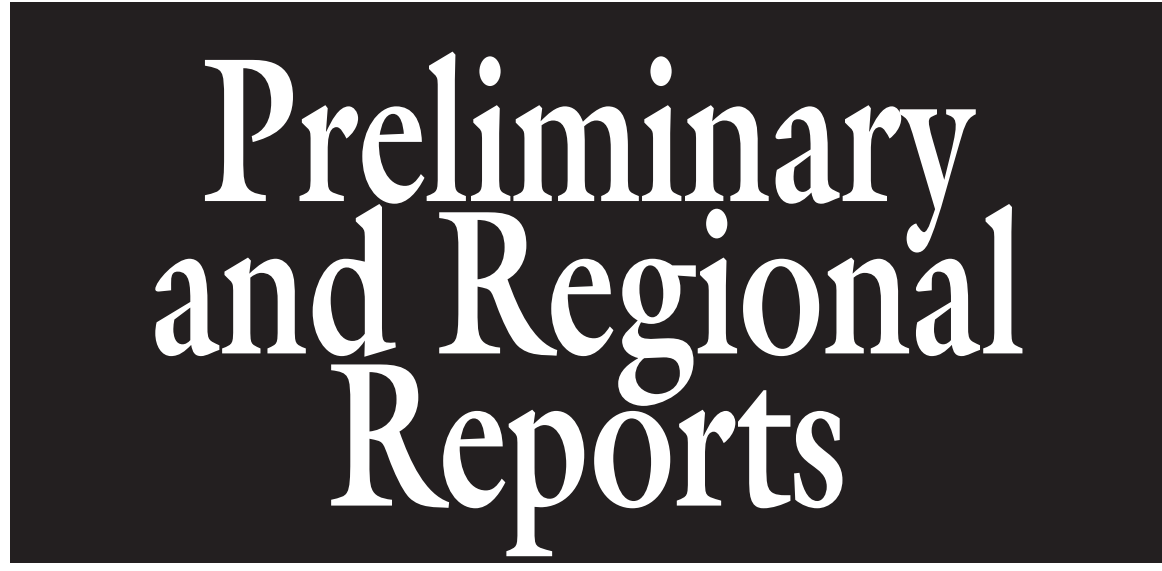

\title{
Quality of Strawberries Shipped by Truck from California to Florida as Influenced by Postharvest Temperature Management Practices
}

\author{
William Pelletier ${ }^{1,5}$, Jeffrey K. Brecht ${ }^{2}$, \\ Maria Cecilia do Nascimento Nunes ${ }^{3}$, and Jean-Pierre Émond ${ }^{4}$
}

AdDITIONAL INDEX wORDs. distribution chain, precooling, respiration rate, retail display, transport, visual quality, weight loss, Fragaria $\times$ ananassa

Summary. Commercial shipments of strawberries (Fragaria $\times$ ananassa) were evaluated from the harvest point to the distribution center (DC). Simulated retail conditions were afterward imposed on the fruit. Commercially harvested 'San Juan' strawberries in California were instrumented in the field for temperature and relative humidity $(\mathrm{RH})$ monitoring during handling and distribution. At the cooling facility, five different treatments were imposed on five pallets of strawberries: prompt precooling to a final temperature of 1.7 or $10.0^{\circ} \mathrm{C}, 4$-hour delayed precooling to a final temperature of 1.7 or $10.0^{\circ} \mathrm{C}$, and no precooling. Immediately before being loaded into the trailer, all pallets were wrapped in a modified atmosphere (MA) pallet shrouds. Upon arrival at the DC in Florida, fruit from the same five pallets were exposed to three simulated retail temperatures $(0,6$, and $21^{\circ} \mathrm{C}$ ) for 3 days. Results from this study showed that the refrigerated trailer was unable to maintain the temperature of any of the pallets during transport. In addition, upon arrival at the DC in Florida, strawberries from the partial precooling (cooled to $10.0^{\circ} \mathrm{C}$ ), 4-hour delayed precooling, and no precooling treatments had higher water loss and lower visual quality compared with fruit that were immediately precooled to a final temperature of $1.7^{\circ} \mathrm{C}$. On the basis of the quality control standards of the cooling facility in California, most of the fruit from the no precooling treatment were considered unacceptable for shipment 1 day after harvest. During simulated retail display, quality of the fruit held at $21{ }^{\circ} \mathrm{C}$ was inferior to that of fruit maintained at 0 or $6{ }^{\circ} \mathrm{C}$, particularly that of fruit from the partial and delayed precooling treatments. Strawberries from the prompt precooling to a final temperature of $1.7^{\circ} \mathrm{C}$ treatment had acceptable visual quality after simulated retail display for 3 days at $0{ }^{\circ} \mathrm{C}$, whereas visual quality of the fruit from the delayed or partial precooling treatments ranged from slightly poor to poor after the same period of time. The presence of bruises due to mechanical damage shortened the shelf life of the fruit because of accelerated development of decay. Overall, results obtained from this study highlight the importance of prompt precooling and the use of optimum storage temperature (i.e., $0^{\circ} \mathrm{C}$ ) throughout the distribution chain and during retail display.

trawberries are a very popular item in retail stores. However, they are highly perishable and have a relatively short shelf life, even when handled under optimum conditions. Poor temperature management during distribution and mechanical damage are the main factors that contribute to a reduction in strawberry quality and shelf life. Consequently, strawberry fruit should be promptly and adequately cooled after harvest and maintained refrigerated (i.e., at temperatures between 0 and $1^{\circ} \mathrm{C}$ ) at all steps during the distribution chain.

The first link of the strawberry distribution chain consists of removing the field heat from the fruit as soon as possible after harvest, usually by forced air cooling. The importance of prompt precooling on strawberry quality is well documented. Baird and Gaffney (1976) described precooling as the most important operation to maintain the quality of fresh commodities. In the case of strawberries, a delay of $\mathrm{l} \mathrm{h}$ before precooling may result in a loss of $1 \mathrm{~d}$ of shelf life at near $0{ }^{\circ} \mathrm{C}$ (Mitchell et al., 1996). Effects of such delays not only negatively affect the visual quality characteristics of the fruit but also its chemical composition and nutritional value (Nunes et al., 1995b).

Once precooled, the fruit are usually transported in refrigerated trailers from the cooling facility to the retail DCs, international forwarders, or other intermodal facilities. Over the last 20 years, refrigerated trailers used to transport fresh produce have changed considerably. Among the main changes, the trailers are now longer $(\approx 16 \mathrm{~m})$, their walls are thinner to reduce weight, their refrigeration capacity has increased, their temperature control systems have improved, they have better air delivery chutes, and also more channel floor cross-sectional area for the return air (LeBlanc and Hui, 2005 ).

The environmental conditions encountered during road transportation of strawberry shipments were studied by Harvey (1982) and Harvey et al., (1980). The authors evaluated the effects of a MA packaging (MAP) system on the fruit temperature and incidence of decay during shipments from California to Philadelphia and New York. The MAP system (Tectrol@; TransFresh Corp., Salinas, CA) consists of an entire pallet of strawberries wrapped in a thick plastic shroud, which to accelerate the stabilization of the gas concentrations, is initially purged with a mixture of gases with high carbon dioxide $\left(\mathrm{CO}_{2}\right)$ levels $(10 \%$ to $20 \%)$. The main advantage of this 
MAP system is that the high $\mathrm{CO}_{2}$ atmosphere created inside the pallets contributes to a decrease in decay, whereas helping to retain the firmness and fresh appearance of the fruit (El-Kazzaz et al., 1983; Harker et al., 2000; Harvey, 1982; Harvey et al., 1980; Pelayo et al., 2003). Results reported by Harvey (1982) and Harvey et al. (1980) showed that the strawberry temperatures are on average $1{ }^{\circ} \mathrm{C}$ higher during shipment for pallets using a MAP system compared with uncovered pallets. The MAP system that was tested at that time is still widely used today.

For strawberries intended for domestic markets, the load may wait up to $\mathrm{l} d$ upon arrival at the DC before being distributed to regional retail stores. At the DC, strawberries are usually stored under conditions relatively close to their optimum storage temperature of $0{ }^{\circ} \mathrm{C}$. However, once on display at the retail stores, strawberries, as well as other fruits and vegetables, are often exposed to detrimental temperatures (LeBlanc et al., 1996; Nunes et al., 2008; Villeneuve, 1999). LeBlanc et al. (1996) measured an average temperature of $7.6{ }^{\circ} \mathrm{C}$ in the winter and $8.4^{\circ} \mathrm{C}$ in the summer inside retail displays containing fruits and vegetables. Nunes et al. (2008) also observed that, depending on the location inside the refrigerated displays, strawberries are subjected to temperatures ranging from -1.0 to $18.0^{\circ} \mathrm{C}$. In the case of strawberries (and other small fruits), it is also a common commercial practice to display them in non-refrigerated displays to stimulate an impulsive purchase, as the intensity of the aroma released by the fruit increases when exposed to ambient temperature. These practices are responsible in part for the large number of strawberries and other fruits and vegetables wasted at the retail level (Nunes et al., 2008).

\footnotetext{
${ }^{1}$ Center for Food Distribution and Retailing, Agricultural and Biological Engineering Department, University of Florida, IFAS, Gainesville, FL 32611-0570

${ }^{2}$ Center for Food Distribution and Retailing, Horticultural Sciences Department, University of Florida, IFAS, Gainesville, FL 3261 1-0690

${ }^{3}$ Food Quality Laboratory, University of South Florida Polytechnic, 4100 South Frontage Road, Building 100, Suite 112, Lakeland, FL 33815

${ }^{4}$ College of Technology and Innovation, University of South Florida Polytechnic, 3433 Winter Lake Road, Lakeland, FL 33803

${ }^{5}$ Corresponding author. E-mail: willpell@ufl.edu.
}

Although it is assumed that temperature during handling and shipping is critical to maintain fruit quality, information is rather scarce about what happens during real commercial shipments of strawberries from the growers to the retail stores, and, to our knowledge, no similar studies yet have been conducted in this area. The objectives of this study were: 1) determine the effects of various postharvest temperature management practices, from the grower to the retail stores, on the quality of strawberries; and 2) identify the steps during the cold chain that are most critical for maintaining the quality of strawberries. More specifically, for this commercial scale study, all steps from harvest to the retail store level were studied with deliberate manipulations of the strawberry handling practices imposed on selected pallets to simulate different potential occurrences related to temperature management. Temperature and $\mathrm{RH}$ were monitored from the field to the DC, and visual quality of the strawberries was subsequently evaluated on a daily basis under simulated retail conditions.

\section{Materials and methods}

Benchmark Shipments. Before the full-scale test, which is the main focus of this study, two benchmark shipments were conducted in July 2005 on full loads of strawberries shipped by truck from California to Florida. For the two benchmark shipments, the temperature was monitored in three pallets of strawberries located at the front, center, and back of a trailer. All three pallets were located on the right hand side of the trailer, which is facing south while traveling eastbound and is supposedly exposed to the highest temperatures. For these two tests, temperature sensors were installed after the fruit were precooled, $\approx \mathrm{l} \mathrm{d}$ before departure from California. Air and pulp temperatures were measured. The weight of the three clamshells in each of the instrumented pallets was also measured before and after the 4-d shipment. Temperature and weight measurements were conducted with the same equipment and using the same methodology as those presented in the following sections of this article. The MA pallet shroud system (Tectrol@) was used on all of the pallets for both the benchmark tests.

Plant material and temperaTURE. In a test conducted in Sept.Oct. 2005, the behavior of a full load [i.e., 24 pallets (Fig. 1A)] of strawberries shipped by truck from California to Florida was once again studied, but this time with imposed temperature management treatments. For this test, 11 pallets of 'San Juan' strawberries that had been commercially harvested were instrumented on 28 Sept. 2005. The fruit were packed in clear plastic clamshells with a net commercial weight of $1 \mathrm{lb}$ each. A total of 864 clamshells formed a pallet ( 1 pallet $\times 18$ layers $\times 6$ flats per layer $\times 8$ clamshells per flat $=864$ clamshells). Three out of 864 clamshells that composed a pallet were instrumented for temperature and $\mathrm{RH}$ monitoring. The temperature and $\mathrm{RH}$ sensors were placed on the threedimensional diagonal of the pallet, that is, at a bottom corner, in the center, and at the opposite, top corner (Fig. 1B). The data loggers $\left(\mathrm{HOBO}{ }^{\circledR}\right.$ Series $\mathrm{H} 8$; Onset Computer Corp., Bourne, MA) used to collect the data were each equipped with one internal temperature sensor and one internal RH sensor, plus an external TMC6-HA temperature probe (Onset Computer Corp.), with accuracy values of $\pm 0.7{ }^{\circ} \mathrm{C}, \pm 5 \%(25 \%$ to $95 \% \mathrm{RH}$ range), and $\pm 0.5{ }^{\circ} \mathrm{C}$, respectively. Data loggers were placed between clamshells to measure air temperature and $\mathrm{RH}$, whereas the temperature probes were inserted into

\begin{tabular}{llll}
\hline $\begin{array}{l}\text { Units } \\
\text { To convert U.S. to SI, } \\
\text { multiply by }\end{array}$ & U.S. unit & SI unit & $\begin{array}{l}\text { To convert SI to U.S., } \\
\text { multiply by }\end{array}$ \\
\hline $1.0551 \times 10^{3}$ & $\mathrm{Btu}$ & $\mathrm{J}$ & $9.4782 \times 10^{-4}$ \\
0.3048 & $\mathrm{ft}$ & $\mathrm{m}$ & 3.2808 \\
36.1273 & inch $/ \mathrm{lb}$ & $\mathrm{mL} \cdot \mathrm{kg}^{-1}$ & 0.0277 \\
$4.1840 \times 10^{4}$ & $\mathrm{kcal}$ & $\mathrm{J}$ & $2.3900 \times 10^{-4}$ \\
0.4536 & $\mathrm{bb}$ & $\mathrm{kg}$ & 2.2046 \\
$2.7680 \times 10^{4}$ & $\mathrm{lb} / \mathrm{inch}^{3}$ & $\mathrm{mg} \cdot \mathrm{mL}^{-1}$ & $3.6134 \times 10^{-5}$ \\
$1 \times 10^{6}$ & $\mathrm{lb} / \mathrm{lb}$ & $\mathrm{mg} \cdot \mathrm{kg}^{-1}$ & $1 \times 10^{-6}$ \\
$\left({ }^{\circ} \mathrm{F}-32\right) \div 1.8$ & ${ }^{\circ} \mathrm{F}$ & ${ }^{\circ} \mathrm{C}$ & $\left(1.8 \times{ }^{\circ} \mathrm{C}\right)+32$ \\
& & &
\end{tabular}




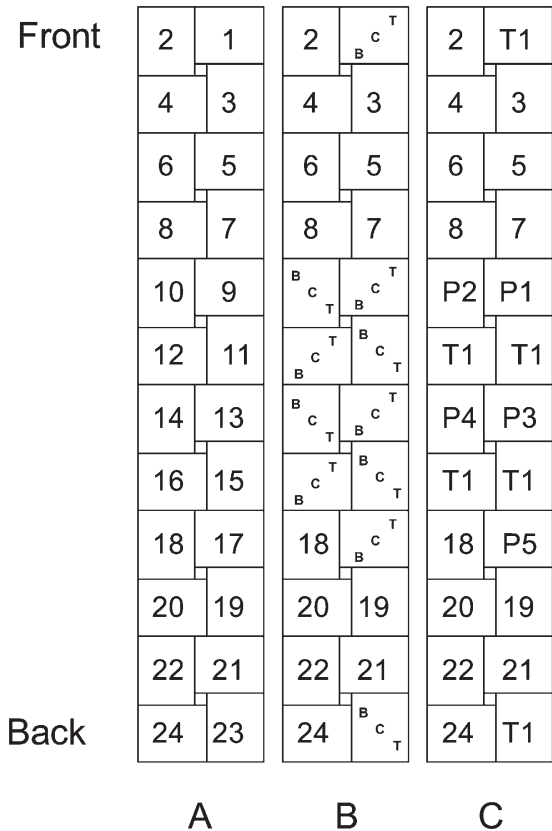

Fig. 1. Schematic of a transport trailer with (A) pallet position numbers, (B) sensor locations, and $(C)$ positions of the field-instrumented pallets $(P$ pallets) as well as the cooling facilityinstrumented pallet ( $T$ pallets). For (B), B = bottom of the pallet, $\mathrm{C}=$ center of the pallet, $\mathrm{T}=$ top of the pallet. For $P x$ and T $x$ pallets $(\mathrm{C})$, " $x$ " refers to the precooling treatments: $x=1$ (immediate and complete precooling), $x=2$ (delayed but complete precooling), $x=3$ (immediate but incomplete precooling), $x=4$ (delayed and incomplete precooling), $x=5$ (no precooling or refrigeration before transport).

individual fruit located in the center of the clamshell for each of the three instrumented clamshells (bottom corner, center, and opposite top corner on each of the 11 pallets). The calibration of the data loggers was verified in an agitated ice bath before the shipment.

A total of five pallets (i.e., 15 clamshells) were instrumented in the field and then transported from the field to the cooling facility on an openbed truck within $\approx 30 \mathrm{~min}$. The five field-instrumented pallets were used for the precooling treatments described below. An additional six pallets (i.e., 18 clamshells) of strawberries harvested the day before, already precooled and in cold storage, were instrumented at the cooling facility for a total of 11 pallets and 33 clamshells. Because the latter six pallets were intended to be sold at retail, pulp temperatures were not measured to avoid causing puncture marks on the fruit. Instead, the probes were placed in contact with the surface of the fruit in the center of the clamshells. For these six pallets, data loggers were placed at the exact same locations as for the five field-instrumented pallets. The five field-instrumented pallets were identified as $\mathrm{P} x(y)$ pallets, whereas the six cooling facility-instrumented pallets were identified as $\mathrm{T} x(y)$ pallets. The numbers " $x$ " refer to the precooling treatments, whereas the numbers " $y$ " in parentheses refer to the position of the pallet in the refrigerated trailer (Fig. 1C).

Precooling treatments. Upon arrival at the cooling facility, five different precooling treatments were applied to the five field-instrumented pallets (P pallets). Pallet $\mathrm{Pl}(9)$ was precooled without delay to a final fruit pulp temperature of $1.7^{\circ} \mathrm{C}$; pallet $\mathrm{P} 2(10)$ was left outside the facility without any protection from the sun and wind for a delay period of $4 \mathrm{~h}$, and then precooled to a final fruit pulp temperature of $1.7^{\circ} \mathrm{C}$; pallet $\mathrm{P} 3(13)$ was precooled without delay to a final fruit pulp temperature of $10^{\circ} \mathrm{C}$; pallet $\mathrm{P} 4$ (14) was left outside the cooling facility without any protection from the sun and wind for a delay period of $4 \mathrm{~h}$ and then precooled to a final fruit pulp temperature of $10{ }^{\circ} \mathrm{C}$; and pallet P5(17) was left outside the facility and neither precooling nor refrigeration was applied before transport the following day. Pallets $\mathrm{Pl}(9), \mathrm{P} 2(10)$, $\mathrm{P} 3(13)$, and P4(14) were precooled individually. The final pulp temperature of $1.7^{\circ} \mathrm{C}$ for pallets $\mathrm{Pl}(9)$ and P2(10) was chosen in accordance with the precooling procedures used as a commercial standard at the facility involved in this study. The final temperature of $10^{\circ} \mathrm{C}$ for pallets $\mathrm{P} 3(13)$ and P4(14) was chosen on the basis of our experience as a realistic detrimental temperature management scenario. The 4-h delay before precooling of pallets P2(10) and P4(14) was chosen to simulate an extended waiting period in the field or a long distance transport from the field to the cooling facility. The no precooling treatment applied to pallet P5(17) was selected to compare other breaks in the cold chain with the worst-case scenario of neither precooling nor refrigeration before shipping. To follow the normal commercial precooling procedures used at the facility involved in this study, all the pallets were physically rotated $180^{\circ}$ once during precooling to obtain a more uniform temperature distribution. To stop the precooling at the correct temperature $\left[1.7^{\circ} \mathrm{C}\right.$ for pallets $\mathrm{Pl}(9)$ and $\mathrm{P} 2(10)$ or $10{ }^{\circ} \mathrm{C}$ for pallets $\mathrm{P} 3(13)$ and $\mathrm{P} 4(14)]$, three T-type thermocouples (24 gauge) (Omega Engineering, Stamford, CT) that had been previously installed were used. The thermocouples were equidistantly located in strawberry fruit on the ninth layer of the pallets (center), parallel to the airflow. Pulp temperatures were measured and thermocouple readings were monitored in real time using a thermocouple thermometer (model 819; Tegam, Geneva, $\mathrm{OH}$ ) and a multiprobe switchbox (model 8052, Tegam). The precooling operation was stopped as soon as the average of the three thermocouples was equal to the desired final temperatures. The calibration of the thermocouple thermometer was verified in an agitated ice bath before the experiment.

COLD STORAGE AND MA PALlet SHROUD PROCEDURES. Four of the five field-instrumented pallets $\mathrm{Pl}(9)$ to P4(14) and the six cooling facilityinstrumented pallets (T pallets) were stored at $0{ }^{\circ} \mathrm{C}$ until their departure for Florida, which corresponded to approximate storage periods of 1 and $2 \mathrm{~d}$ after harvest, respectively. Pallet P5(17) was never stored in a cold room. All 11 pallets [including P5(17)] were covered with a MA pallet shroud and immediately loaded into the trailer. The operation involved covering the pallet with a polyethylene shroud, sealing the shroud to the base of the pallet with tape, pumping out a portion of the air within the pallet shroud, and replacing the removed air with $\mathrm{CO}_{2}$ to give a final atmosphere containing $\approx 1 \%$ to $11 \%$ oxygen and $10 \%$ to $20 \% \mathrm{CO}_{2}$ (balance nitrogen).

Transport From THE COOLING FACILITY IN CALIFORNIA TO THE DC IN FLORIDA. The $53-\mathrm{ft}$ trailer used for the transport of the strawberries in the shipping test reported here was a 2004 model in good condition. The unit was equipped with a chute for air delivery at the back of the trailer, and the refrigeration system was a Thermo King SB Classic (Thermo King Corp., Minneapolis, $\mathrm{MN})$. The trailer load was composed of 24 pallets loaded in a pinwheel configuration (braced away from the wall). Figure 1 shows three schematics 
of the trailer, the pallet position numbers (Fig. 1A), the sensor locations (Fig. $\mathrm{IB})$, and the positions of the $\mathrm{P}$ and $\mathrm{T}$ pallets (Fig. IC). The $\mathrm{T}$ pallets were positioned so as to be adjacent to pallets $\mathrm{Pl}(9), \mathrm{P} 2(10), \mathrm{P} 3(13), \mathrm{P} 4(14)$, and P5(17). This was done to avoid the potentially warmer pallets [i.e., $\mathrm{P} 3(13)$, P4(14), and P5(17)] from affecting the temperature distribution in pallets $\mathrm{Pl}(9)$ and $\mathrm{P} 2(10)$, which could have introduced error into the evaluation of the effects of the different precooling treatments. Furthermore, the temperature distribution among the $\mathrm{T}$ pallets provided information on the impact of adjacent warmer pallets. Before departure, the truck cooling unit was set to $34^{\circ} \mathrm{F}$ for the trip, and the shipment left the cooling facility in California on 29 Sept. 2005 ( 1 or 2 d after harvest for pallets $\mathrm{P}$ and $\mathrm{T}$, respectively). The shipment arrived at the DC in Florida on 3 Oct. 2005 ( 4 d later), but the trailer was not unloaded until the next morning (4 Oct. 2005). After unloading, the MA pallet shrouds were removed, the data loggers were collected, and the weight of each instrumented clamshell was measured. Pallets $\mathrm{Pl}(9)$ to P5(17) were then loaded on an enclosed non-refrigerated truck and carried to the University of Florida laboratory in Gainesville within $3 \mathrm{~h}$. Upon arrival at the laboratory, the strawberries were stored in a cold room at $0.0 \pm 0.1{ }^{\circ} \mathrm{C}$ for $24 \mathrm{~h}$.

Retail Display simulation. The effect of the five different precooling treatments, the clamshell location within the pallet (bottom, center, and top), and the effect of different retail temperatures $(0,6$, and $21{ }^{\circ} \mathrm{C}$ ) on the visual quality of the strawberries were evaluated. Retail temperatures were chosen as representative of the optimum temperature for handling and storage of strawberries (i.e., $0{ }^{\circ} \mathrm{C}$ ), a temperature normally encountered during retail display (i.e., $6{ }^{\circ} \mathrm{C}$ ), and an abuse temperature that simulated conditions of a nonrefrigerated display case (i.e., $21^{\circ} \mathrm{C}$ ). This scenario was chosen as representative of measurements taken in our previous study over a 1 -year period (Nunes et al., 2008) and also based on data found in the literature (LeBlanc et al., 1996). During the retail simulation, the temperature and $\mathrm{RH}$ of the three storage rooms were maintained at $0.0 \pm 0.5^{\circ} \mathrm{C}$ and $95 \% \pm 5 \% \mathrm{RH}, 6.0 \pm$ $0.5^{\circ} \mathrm{C}$ and $81 \% \pm 5 \% \mathrm{RH}$, and $20.8 \pm$
$0.5{ }^{\circ} \mathrm{C}$ and $86 \% \pm 5 \% \mathrm{RH}$. However, for the sake of simplicity storage conditions will be referred as 0,6 , and $21{ }^{\circ} \mathrm{C}$ throughout the text.

WEIght LOSS AND VISUAL QUALITY EVALUATION. The weight of all instrumented clamshells (from $P$ and $\mathrm{T}$ pallets) was measured using a scale with $\pm 0.1 \mathrm{~g}$ accuracy (Scout Pro SP 2001; Ohaus Corp., Pine Brook, NJ). The weight of the three single clamshell on each of the five field-instrumented pallets ( $P$ pallets) was measured at harvest and after arrival at the DC in Florida. The weight of the three single clamshell on each of the six facility-instrumented pallets ( $\mathrm{T}$ pallets) was measured $\mathrm{l} \mathrm{d}$ before departure and after arrival at the DC in Florida.

The average quality rating was calculated for 18 clamshells in each pallet before the retail simulation (the day after arrival at the laboratory in Gainesville). During the retail display simulation, the visual quality of the selected clamshells was monitored daily over a 3 -d period (Fig. 2). The strawberry visual quality was assessed using a $1-5$ visual rating scale, where
5 = very good (freshly harvested fruit, fruit are firm and turgid, there are no signs of bruising, shriveling, or decay); $4=\operatorname{good}$ (fruit are firm but with some small bruises); 3 = fair (fruit exhibit minor signs of softness, shriveling is evident, and bruises are visible, but there is no visible decay); $2=$ poor (fruit are very soft, very bruised, overripe, have wilted and dry calyces, and decay is evident on some fruit); $\mathrm{l}=$ very poor (fruit are extremely overripe, with extremely wilted and dry calyces, there are leaky fruit, and partially or completely rotten fruit) (Nunes et al., 2003). A clamshell container of fruit with a visual rating of 2.0 was considered to be still acceptable for sale under normal retail requirements.

Statistical analysis. A completely randomized design was used to determine differences in weight loss and visual quality of the strawberries used in the simulated retail display treatments. The treatments were a $5 \times 3 \times 3$ arrangement of five different precooling treatments (precooled without delay to a final fruit pulp temperature of $1.7^{\circ} \mathrm{C}$, delayed

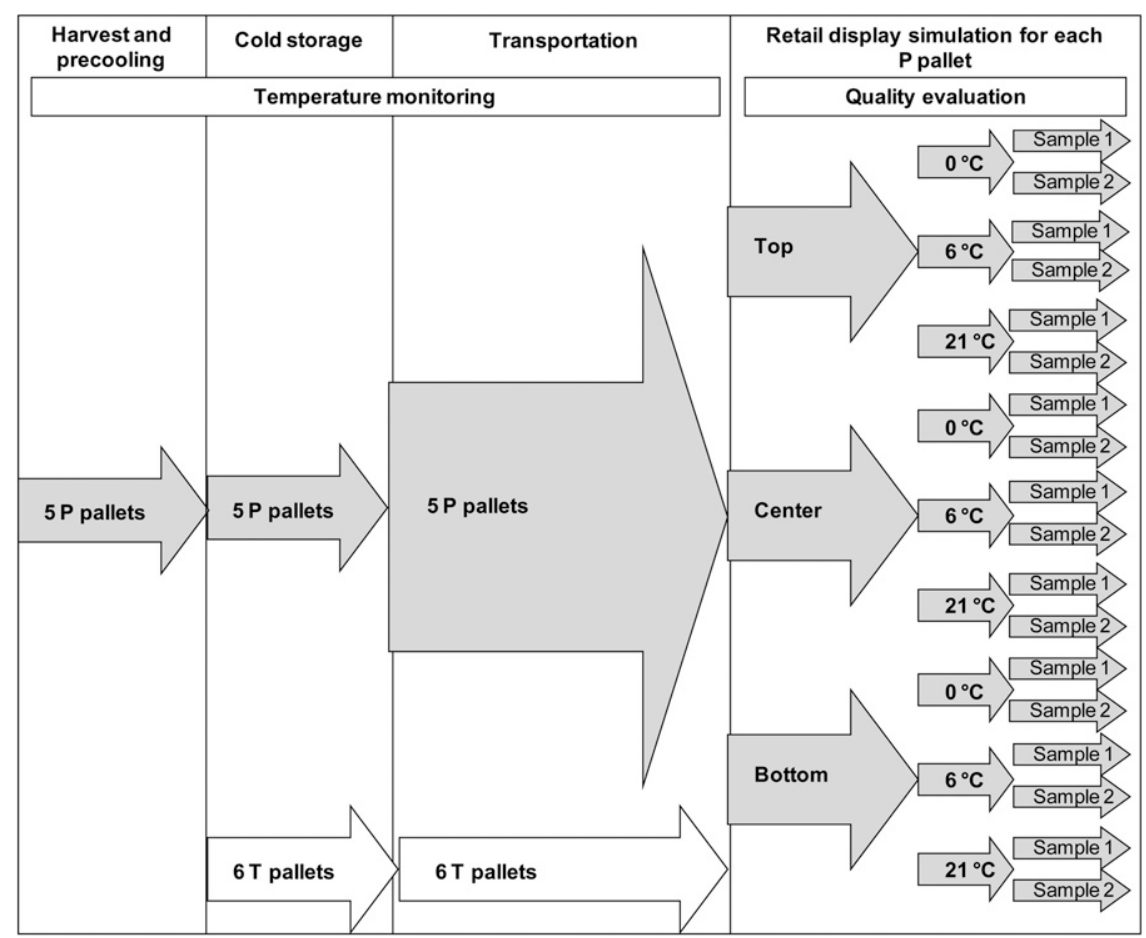

Fig. 2. Schematic of the experimental design $\left[0,6\right.$, and $21{ }^{\circ} \mathrm{C}(32.0,42.8$, and 69.8 $\left.\left.{ }^{\circ} \mathrm{F}\right)\right]$. The $5 \mathrm{P}$ pallets were instrumented in the field and then subjected to five different precooling treatments: 1 (immediate and complete precooling), 2 (delayed but complete precooling), 3 (immediate but incomplete precooling), 4 (delayed and incomplete precooling), and 5 (no precooling or refrigeration before transport). The $6 \mathrm{~T}$ pallets were instrumented while they were in cold storage $\left(0{ }^{\circ} \mathrm{C}\right), 1 \mathrm{~d}$ after they were precooled $(1=$ immediate and complete precooling $)$. 
precooling to a final fruit pulp temperature of $1.7^{\circ} \mathrm{C}$; precooled without delay to a final fruit pulp temperature of $10^{\circ} \mathrm{C}$, delayed precooling to a final fruit pulp temperature of $10{ }^{\circ} \mathrm{C}$; noprecooling), three different positions within a pallet (top, center, and bottom), and three simulated retail display temperatures $\left(0,6\right.$, and $\left.21^{\circ} \mathrm{C}\right) \times$ two replicate samples (i.e., two clamshells containing $\approx 19$ berries each). There were, therefore, a total of 90 clamshells used in this study (i.e., 18 clamshells from each of the five pallets). A schematic of the experimental design is shown in Fig. 2. Analysis of variance was performed using SAS (version 9.1; SAS Institute, Cary, NC). Data from the three locations on a pallet were combined and analyzed simultaneously as initial statistical analysis showed no significant differences between locations in the pallet for weight loss and visual quality. Linear correlation analysis using Pearson's correlation coefficient $(r)$ was used to relate temperature of the fruit at the center of the pallet and estimated respiration rate of the fruit.

\section{Results and discussion}

BENCHMARK SHIPMENTS. The two benchmark shipments showed significant increases in temperature during transport. In some cases, pulp temperatures rose from 1.5 to $6{ }^{\circ} \mathrm{C}$ during the 4 - $d$ trip. In all cases, the air and pulp temperatures at the center of the pallets increased linearly during the shipments, which indicated a very low rate of heat transfer at that location. In both tests, pallets positioned in the front of the trailer were maintained at the lowest temperatures. Day-night cyclic temperature variations were obvious at bottom and top locations of all pallets in one of the shipment only. Discrepancies were also noticed in initial temperatures (just before shipment). In some pallets, temperatures were initially between 0.5 and $1.0^{\circ} \mathrm{C}$ whereas others ranged between 2.0 and $2.5{ }^{\circ} \mathrm{C}$. These differences in temperatures were potentially caused by variations in the precooling operations. For both benchmark shipments, all weight loss measurements were below $0.9 \%$ over the 4-d period.

FIELD AND PRECOOLING TEMPERATURE PROFILES. A period of about $30 \mathrm{~min}$ after the sensors were installed was required for thermal stabilization to occur (data not shown). The air and fruit pulp temperatures varied between 20.0 and $24.0^{\circ} \mathrm{C}$ during the period following the sensor installation and arrival of the instrumented pallets ( $\mathrm{P}$ pallets) at the cooling facility. During the 4 -h delay before precooling, the temperatures of both pallets $\mathrm{P} 2(10)$ and $\mathrm{P} 4(14)$ were relatively constant, varying between 20.0 and $24.0^{\circ} \mathrm{C}$, except for the pulp temperature of the fruit located on the top position of pallet $\mathrm{P} 4(14)$, which rose to $26.0^{\circ} \mathrm{C}$. Simultaneously, a small temperature increase (to $24.4^{\circ} \mathrm{C}$ ) was recorded in the temperature of the air, which might have been caused by exposure to direct solar radiation.

Pulp temperature measured in the fruit located in the top position of pallet P5(17) increased up to $28.3^{\circ} \mathrm{C}$, whereas the air temperature in the top layer of the same pallet reached only $24.4^{\circ} \mathrm{C}$. This may be explained by the fact that the strawberry that was instrumented was directly exposed to the sun, whereas the data logger used to collect the temperature of the air was shaded. There was no significant difference between the pulp and the air temperatures at the center of the load. Because of the significant thermal inertia of the pallet core, both temperatures remained relatively constant, between 19.0 and $22.0{ }^{\circ} \mathrm{C}$ for the entire period before transport. The bottom pulp and air temperatures varied between 15.2 and $23.6{ }^{\circ} \mathrm{C}$; there was no significant difference between them. During the night, the coldest temperature recorded was $14.1^{\circ} \mathrm{C}$ for the top position in the pallet. During the following day, a maximum temperature of $21.7^{\circ} \mathrm{C}$ was reached at the same location. Larger temperature variations were observed at the top than at the bottom position of the pallet because of higher convective and radiative heat transfer.

Precooling durations were relatively short because the pallets were precooled individually on systems designed to handle 10 pallets simultaneously. Precooling durations and final temperatures at the different locations within the pallets are shown in Table 1. The thermal inertia of the fruit was responsible for large differences between the pulp and air temperatures during the cooling process. Pallet $\mathrm{Pl}(9)$ was precooled until the average fruit pulp temperature was
$1.6{ }^{\circ} \mathrm{C}$, and the final pulp temperatures at the bottom, center, and top of the pallets were not much different from that value $\left(1.4,2.5\right.$, and $2.0^{\circ} \mathrm{C}$, respectively), which indicates that the cooling process was uniform. Similarly to pallet $\mathrm{Pl}(9)$, pallet $\mathrm{P} 2$ (10) was precooled until the average fruit pulp temperature reached $1.1{ }^{\circ} \mathrm{C}$. Final fruit pulp temperatures at the bottom, center, and top of pallet P2(10) were $1.2,0.3$, and $5.4{ }^{\circ} \mathrm{C}$, respectively. The higher temperature at the top of the pallet $\left(5.4^{\circ} \mathrm{C}\right)$ was most likely caused by inadequate repositioning of the pallet against the seal of the precooler after the pallet was rotated. Consequently, the air bypassed the top corner of the pallet, resulting in a less efficient cooling process at this location. Precooling of pallet P3(13) was shorter because of its final target temperature of $10.0{ }^{\circ} \mathrm{C}$. The final temperatures at the bottom, center, and top were $11.4,10.2$, and $9.4^{\circ} \mathrm{C}$, respectively. This indicates that the precooling was fairly uniform. However, there were major differences in the cooling rates for pallet $\mathrm{P} 4(14)$, and uniformity around the target temperature of $10{ }^{\circ} \mathrm{C}$ was not achieved. After $20 \mathrm{~min}$, the temperatures at the bottom, center, and top of pallet P4(14) were $8.6,2.9$, and $19^{\circ} \mathrm{C}$, respectively. Again, inadequate positioning of the pallet against the seal of the precooler seems to be the most rational explanation for that occurrence.

Cold storage temperature PROFILES. During the cold storage period of $\approx \mathrm{l} \mathrm{d}$ (for $\mathrm{P}$ pallets), the temperatures in pallet $\mathrm{Pl}(9)$ varied between 0.7 and $3.7^{\circ} \mathrm{C}$, and the differences between pulp and air temperatures were relatively small (data not shown). For pallet P2(10), $4 \mathrm{~h}$ after precooling, the temperatures were uniform and maintained between 0.0 and $1.5{ }^{\circ} \mathrm{C}$ for the rest of the storage period. Pallet $\mathrm{P} 3(13)$, which was precooled to about $10^{\circ} \mathrm{C}$, showed that the top of the pallet had the highest heat transfer rate with its surroundings. The top of the pallet reached $1{ }^{\circ} \mathrm{C}$ after $7 \mathrm{~h}$, whereas the bottom and the center barely reached $1{ }^{\circ} \mathrm{C}$ after $24 \mathrm{~h}$. As expected, differences between the air and pulp temperatures decreased with increasing storage duration. Pallet P4(14) showed large differences in the bottom, center, and top temperatures at the end of the precooling operation. The fruit pulp 
temperature at the top of this pallet, which was initially at $19{ }^{\circ} \mathrm{C}$, decreased quickly. After the first $3 \mathrm{~h}$, there was no significant difference between the air temperature and the top layer pulp temperature. The bottom and top layer temperatures of pallet $\mathrm{P} 4(14)$ reached $2{ }^{\circ} \mathrm{C}$ after about $17 \mathrm{~h}$, whereas the center was still slightly above $4{ }^{\circ} \mathrm{C}$ at that time.

TRANSPORT TEMPERATURE PROFILES AND RESPIRATION RATES. The temperature set point of the trailer was $34^{\circ} \mathrm{F}$, but the cooling efficiency of the trailer was reduced since the pallets were wrapped in MA shrouds that prevent forced convective heat transfer within the load. As expected, there was no significant difference between air and pulp temperatures because of the very low rate of heat transfer (Table 2). The analysis of the temperature profiles was therefore focused on pulp temperatures. The low rate of heat transfer or cooling efficiency from the refrigerated trailer is a problem that has been acknowledged by the company supplying the MAP service (TransFresh Corp., 2004). However, TransFresh Corp. states that the Tectrol (C) system accounts for an increase of 1 to $2{ }^{\circ} \mathrm{F}$ only, which is clearly less that what was observed in this study and in the two previous benchmark shipments. Table 2 summarizes initial and final pulp temperatures for all the instrumented pallets, and Figs. 3-5 show the pulp temperature profiles at the bottom (B), center (C), and top ( $\mathrm{T}$ ) locations of the same pallets during transport. No obvious day-night cyclic temperature variations were observed during the test as was the case during one of the benchmark shipments.

Pallet Tl(1) showed an expected normal increase in temperature during transport (Fig. 3); the temperatures at the bottom, center, and top locations in the pallet increased by $1.7,3.0$, and $0.8{ }^{\circ} \mathrm{C}$, respectively. Bottom, center, and top temperatures on pallet $\mathrm{Pl}(9)$ varied notably from each other and, during the trip, increased by $5.8,3.7$, and $2.2^{\circ} \mathrm{C}$, respectively. Pallet P2(10) showed a more uniform and lower temperature distribution during the trip than pallet $\mathrm{Pl}(9)$. During transport, the bottom, center, and top temperatures of pallet P2(10) increased by $3.4,4.7$, and 5.1 ${ }^{\circ} \mathrm{C}$, respectively. Temperature profiles for pallet $\mathrm{Tl}(11)$ were similar to that of

Table 1. Pulp temperature of strawberries before precooling, precooling duration, and fruit temperature after precooling.

\begin{tabular}{|c|c|c|c|c|}
\hline Pallet & Position & $\begin{array}{c}\text { Temp before } \\
\text { precooling }\left({ }^{\circ} \mathbf{C}\right)^{\mathrm{z}}\end{array}$ & $\begin{array}{l}\text { Precooling } \\
\text { times (min) }\end{array}$ & $\begin{array}{c}\text { Temp after } \\
\text { precooling }\left({ }^{\circ} \mathrm{C}\right)\end{array}$ \\
\hline \multirow[t]{4}{*}{$\operatorname{Pl}(9)^{y}$} & Top & 21.7 & 45 & 2.0 \\
\hline & Center & 21.7 & & 2.5 \\
\hline & Bottom & 22.8 & & 1.4 \\
\hline & Ninth row ${ }^{x}$ & - & & 1.6 \\
\hline \multirow[t]{4}{*}{$\mathrm{P} 2(10)$} & Top & 21.0 & 50 & 5.4 \\
\hline & Center & 20.2 & & 0.3 \\
\hline & Bottom & 19.4 & & 1.2 \\
\hline & Ninth row & - & & 1.1 \\
\hline \multirow[t]{4}{*}{ P3(13) } & Top & 22.1 & 23 & 9.4 \\
\hline & Center & 21.3 & & 10.2 \\
\hline & Bottom & 22.1 & & 11.4 \\
\hline & Ninth row & - & & 10.1 \\
\hline \multirow[t]{4}{*}{ P4(14) } & Top & 23.2 & 20 & 19.0 \\
\hline & Center & 21.7 & & 2.9 \\
\hline & Bottom & 20.6 & & 8.6 \\
\hline & Ninth row & - & & 9.2 \\
\hline P5(17) & & $-^{w}$ & - & - \\
\hline
\end{tabular}

${ }^{\mathrm{z}}\left(1.8 \times{ }^{\circ} \mathrm{C}\right)+32={ }^{\circ} \mathrm{F}$.

y $x(y)$, where " $x$ " refers to the precooling treatments and " $y$ " in parentheses refers to the position of the pallet in the refrigerated trailer (Fig. 1): $x=1$ (immediate and complete precooling), $x=2$ (delayed but complete precooling), $x=3$ (immediate but incomplete precooling), $x=4$ (delayed and incomplete precooling), $x=5$ (no precooling nor refrigeration before transport).

${ }^{x}$ Average temperature from three thermocouples located on the ninth layer of the pallets used as a reference to stop the precooling operation. The thermocouples measured pulp temperatures near the outside, center and inside of the pallet with respect to the forced air cooling tunnel.

wPallet P5(17) was not precooled.

Table 2. Pulp temperatures measured in strawberries at the bottom corner, center, and opposite, top corner of pallets before and after transport.

\begin{tabular}{|c|c|c|c|c|c|c|c|c|c|}
\hline \multirow[b]{3}{*}{ Pallet } & \multicolumn{9}{|c|}{$\operatorname{Temp}\left({ }^{\circ} \mathrm{C}\right)^{\mathrm{z}}$} \\
\hline & \multicolumn{3}{|c|}{ Bottom } & \multicolumn{3}{|c|}{ Center } & \multicolumn{3}{|c|}{ Top } \\
\hline & Initial $^{\mathrm{y}}$ & Final $^{\mathrm{x}}$ & Change $^{w}$ & Initial & Final & Change & Initial & Final & Change \\
\hline $\operatorname{Tl}(1)^{\mathrm{v}}$ & 1.2 & 2.9 & 1.7 & 1.6 & 4.6 & 3 & 1.2 & 2 & 0.8 \\
\hline $\operatorname{Pl}(9)$ & 1.8 & 7.6 & 5.8 & 2.9 & 6.6 & 3.7 & 0.7 & 2.9 & 2.2 \\
\hline $\mathrm{P} 2(10)$ & 1.2 & 4.6 & 3.4 & 0.7 & 5.4 & 4.7 & -0.1 & 5 & 5.1 \\
\hline $\mathrm{Tl}(11)$ & 1.2 & 7 & 5.8 & 2.9 & 6.6 & 3.7 & 0.7 & 3.3 & 2.6 \\
\hline $\mathrm{Tl}(12)$ & 2 & 6.2 & 4.2 & 5 & 7.4 & 2.4 & 0.7 & 4.6 & 3.9 \\
\hline P3(13) & 1.6 & 6.2 & 4.6 & 1.2 & 5.4 & 4.2 & 0.3 & 3.3 & 3 \\
\hline P4(14) & 2 & 5.4 & 3.4 & 4.6 & 7 & 2.4 & 1.6 & 4.6 & 3 \\
\hline $\mathrm{Tl}(15)$ & 0.7 & 5.8 & 5.1 & 0.7 & 6.2 & 5.5 & 0.3 & 4.6 & 4.3 \\
\hline $\mathrm{Tl}(16)$ & - & - & - & 1.2 & 5.4 & 4.2 & 0.3 & 3.7 & 3.4 \\
\hline P5(17) & 17.5 & 5.4 & -12.1 & 19.7 & 12.5 & -7.2 & 19 & 2 & -17 \\
\hline $\mathrm{Tl}(23)$ & 1.1 & 3.2 & 2.1 & 1.6 & 4.2 & 2.6 & 0.3 & 2.9 & 2.6 \\
\hline
\end{tabular}

${ }^{\mathrm{z}}\left(1.8 \times{ }^{\circ} \mathrm{C}\right)+32={ }^{\circ} \mathrm{F}$

yTemperature before transport.

xTemperature after transport.

"Change in temperature $=$ final temperature - initial temperature

"T $x(y)$ and P $x(y)$, where " $x$ " refers to the precooling treatments and " $y$ " in parentheses refers to the position of the pallet in the refrigerated trailer (Fig. 1): $x=1$ (immediate and complete precooling), $x=2$ (delayed but complete precooling), $x=3$ (immediate but incomplete precooling), $x=4$ (delayed and incomplete precooling), $x=5$ (no precooling nor refrigeration before transport).

pallet $\mathrm{Pl}(9)$, which was positioned just in front of pallet $\mathrm{Tl}(11)$.

Although pallets P2(10) and $\mathrm{Tl}(12)$ were also positioned in front of each other, the same parallel cannot be made as the latter showed more discrepancy in the temperature distribution. The temperature curves 

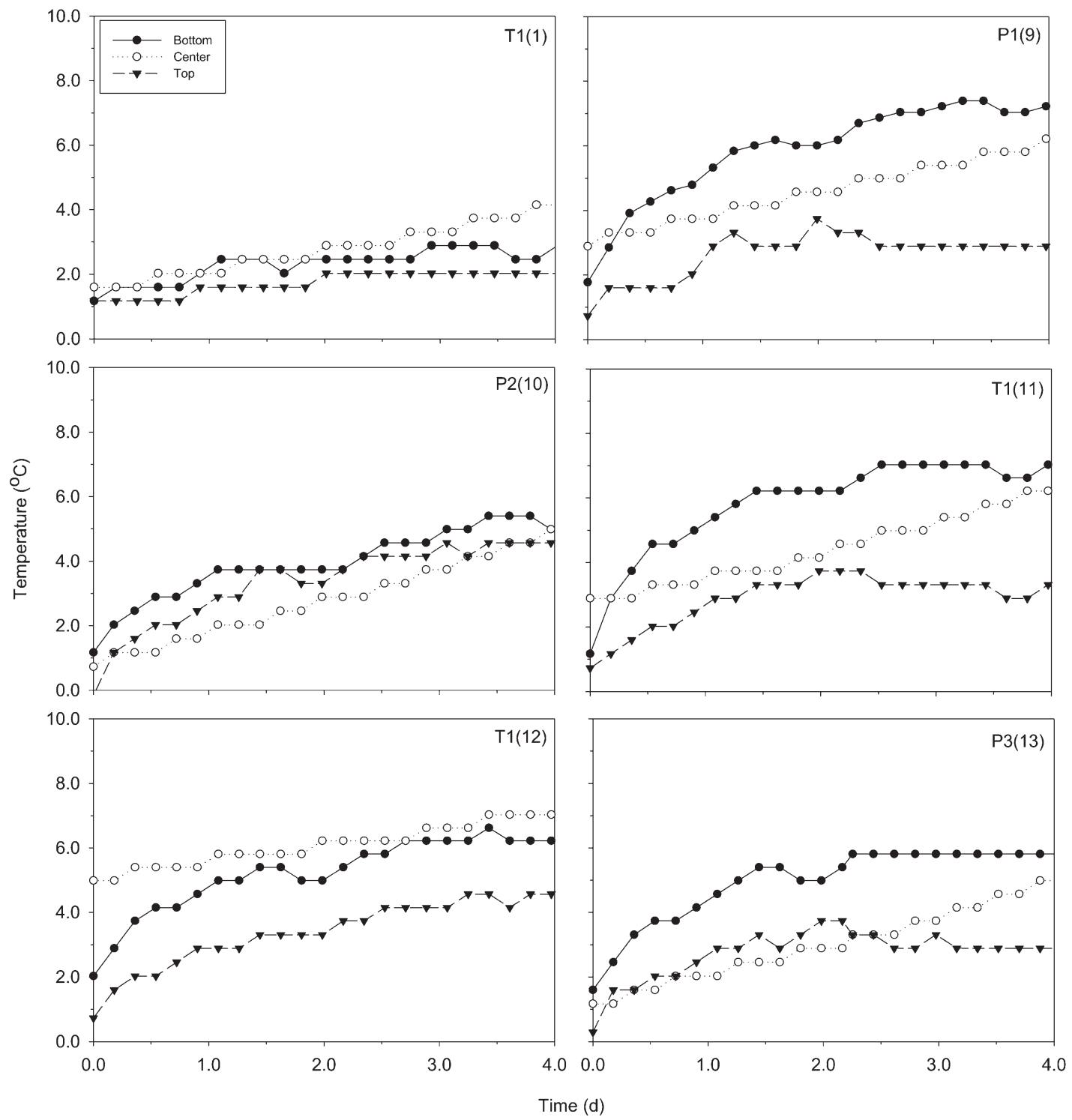

Fig. 3. Temperatures during transport for strawberries from pallets T1(1), P1(9), P2(10), T1(11), T1(12), and P3(13). The $P$ pallets were instrumented in the field and then subjected to different precooling treatments, whereas the T pallets were instrumented while they were in cold storage $\left(0^{\circ} \mathrm{C}\right), 1 \mathrm{~d}$ after they were precooled. For $\mathrm{T} x(y)$ and $\mathrm{P} x(y)$, “ $x$ ” refers to the precooling treatments and " $y$ " in parentheses refers to the position of the pallet in the refrigerated trailer (Fig. 1$) ; x=1$ (immediate and complete precooling), $x=2$ (delayed but complete precooling), $x=3$ (immediate but incomplete precooling); $\left(1.8 \times{ }^{\circ} \mathrm{C}\right)+32={ }^{\circ} \mathrm{F}$.

for the bottom and top position clamshells were similar to those in other pallets but the center temperature was initially unusually high, most likely due to poor precooling. Increases in temperature in pallet $\mathrm{Tl}(12)$ for the bottom, center, and top were 4.2, 2.4, and $3.9^{\circ} \mathrm{C}$, respectively.

For pallet P3(13), trends of the curves were not much different from those observed for the previous pallets. During transport, the bottom, center, and top temperatures increased by 4.6 , 4.2 , and $3.0^{\circ} \mathrm{C}$, respectively. For pallet $\mathrm{P} 4(14)$, the most important difference observed in the temperature profile during transport was the initial center temperature, which was relatively high $\left(4.6{ }^{\circ} \mathrm{C}\right)$ compared with the other P pallets (Fig. 4). No peculiarities were observed in the temperature curves of pallets $\mathrm{Tl}(15)$ and $\mathrm{Tl}(16)$. The bottom sensor in pallet $\mathrm{Tl}(16)$ failed in this test, and therefore, temperature was not recorded. Pallet P5(17) had been neither precooled nor refrigerated, and it showed the most interesting temperature profile since the pallet was loaded into the truck with initial bottom, center, and top fruit pulp temperatures of 17.5, 19.7 , and $19.0^{\circ} \mathrm{C}$, respectively (Table 2 ). After $3 \mathrm{~d}$, the temperature at the top and bottom of the pallet decreased to $\approx 5{ }^{\circ} \mathrm{C}$ (Fig. 5 ). The center temperature increased initially, probably due to heat generated by fruit respiration, to a maximum of $21.6^{\circ} \mathrm{C}$, decreasing slowly afterward to a final temperature of $12.5^{\circ} \mathrm{C}$ as the heat diffused out of the pallet.

Temperature profiles observed for pallet $\mathrm{Tl}(23)$ were similar to those of pallet Tl(1) (Figs. 3 and 4). The ranges of temperatures measured at 


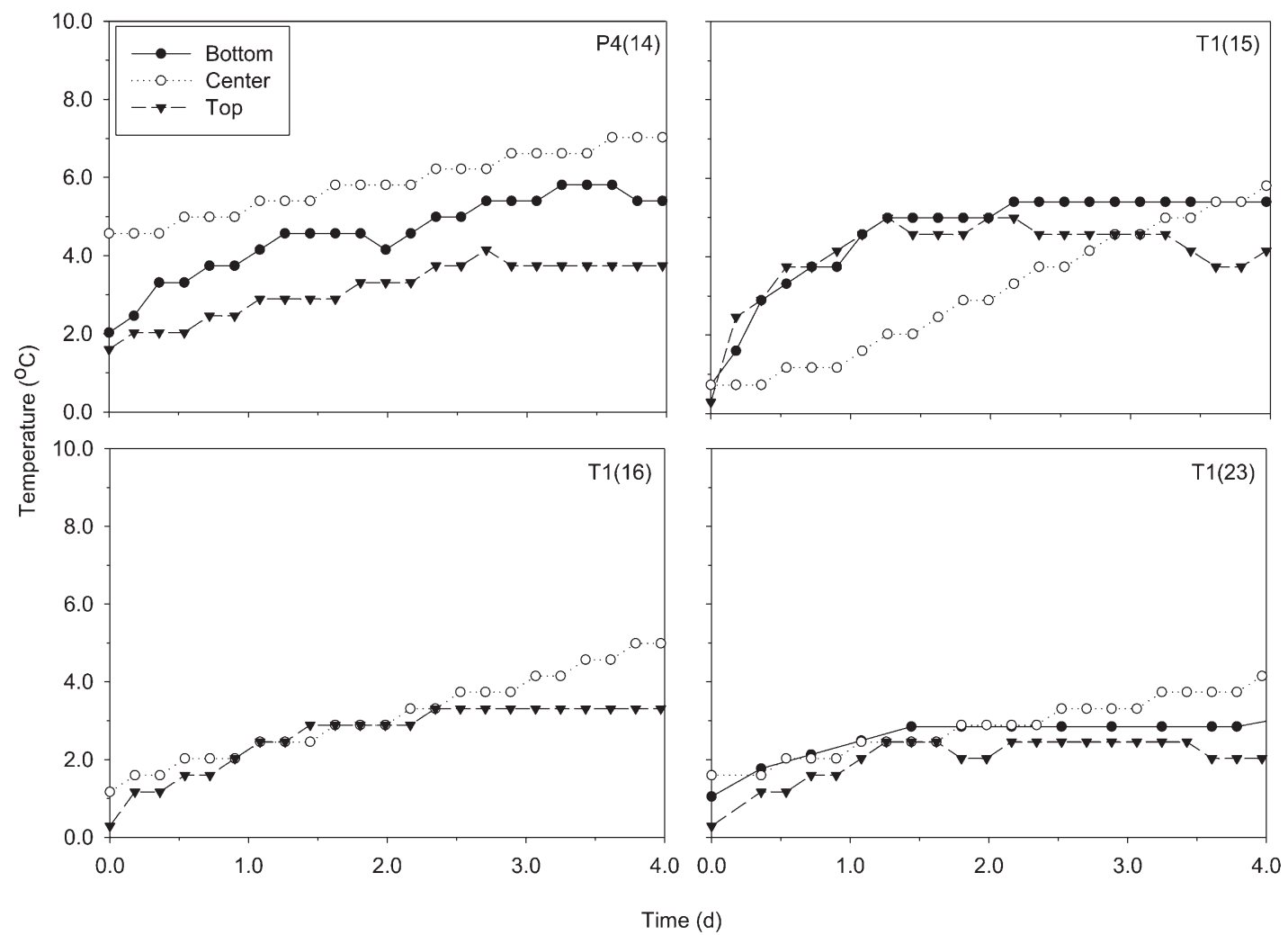

Fig. 4. Temperatures during transport for strawberries from pallets P4(14), T1(15), T1(16), and Tl(23). Pallet P4(14) was instrumented in the field and then subjected to a precooling treatment, whereas the $\mathrm{T}$ pallets were instrumented while they were in cold storage $\left(0^{\circ} \mathrm{C}\right), 1 \mathrm{~d}$ after they were precooled. For T $x(y)$ and $\mathrm{P} x(y)$, " $x$ " refers to the precooling treatments and " $\mathrm{y}$ " in parentheses refers to the position of the pallet in the refrigerated trailer (Fig. 1); $x=1$ (immediate and complete precooling), $x=4$ (delayed and incomplete precooling); $\left(1.8 \times{ }^{\circ} \mathrm{C}\right)+32={ }^{\circ} \mathrm{F}$.

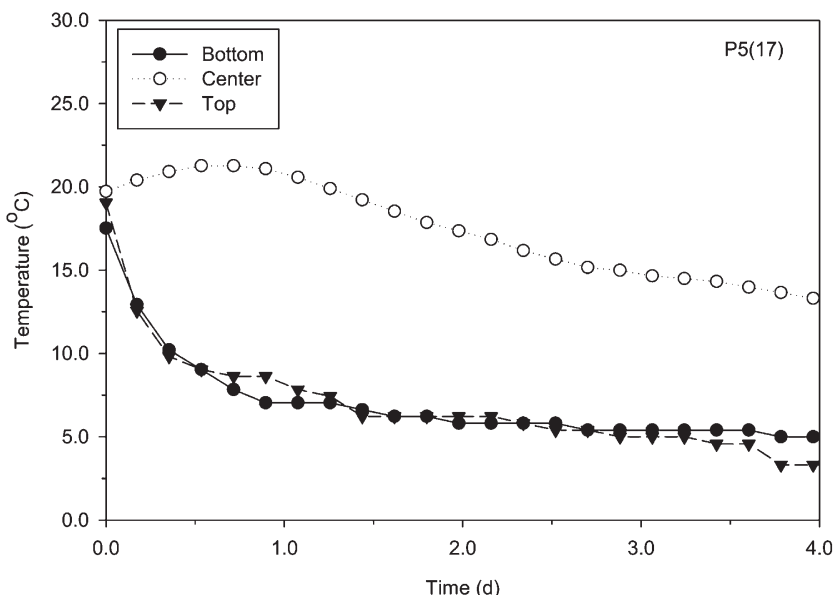

Fig. 5. Pulp temperatures during transport for strawberries from pallet P5(17) [instrumented in the field; treatment 5 (no precooling or refrigeration before transport); position 17 in the refrigerated trailer (Fig. 1)]; $\left(1.8 \times{ }^{\circ} \mathrm{C}\right)+32={ }^{\circ} \mathrm{F}$.

these two locations were the lowest of the whole load, and therefore, the most likely to maintain strawberry quality throughout shipping.

Overall, the temperature profiles during transport showed that even if a pallet is loaded still warm into the truck, such as pallet P5(17), there may be no noticeable effect on the temperature of the colder, adjacent pallets. In addition, although the right side of the trailer (i.e., when looking from the rear toward the front) was mainly facing south during the trip, there was no evidence that temperatures on that side were higher than on the other side. For almost all pallets, the temperature of the bottom fruit was higher than the top fruit, which may be explained by the effect of the radiant heat from the road surface and by the lack of airflow due to the use of the MA pallet shroud.

With the exception of pallet P5(17), which behaved in a totally different way than the other pallets, it is interesting to note that in all cases the increase in temperature measured by the sensors positioned at the center of the pallets happened at a constant rate. Increases in temperature were linear, and even though the initial values were different between pallets, the slopes of the curves were similar. In contrast, the bottom and top curves behaved as typical warming curves and exhibited a tendency to plateau with time as they approached a steady state. The same observation was made with the two benchmark shipments. To explain the observed behavior, two assumptions need to be made: 1) the heat transfer from the surface of a pallet to the center is negligible because of 
the small temperature gradients and the presence of the MA pallet shroud; and 2 ) at all times, the clamshell in the center of the pallet is surrounded by other clamshells at a similar temperature, and therefore, can be considered to be perfectly insulated (negligible heat transfer). On the basis of these assumptions, the only source of heat that may have caused the observed increase in temperature in the fruit in the center clamshells was the heat generated by the fruit respiration. Also, the heat generation can be considered constant because of the relatively small pulp temperature variations observed during the shipment. This is corroborated by the fact that the temperature of a perfectly insulated body with a constant internal heat generation theoretically increases linearly with time. On the other hand, the bottom and top temperature curves reached a plateau since the heat transfer at these locations was sufficient to remove the heat produced by the respiration of the fruit as the temperature gradients increased.

The rates of respiration published for strawberries held at $0{ }^{\circ} \mathrm{C}$ range from 6 to $10 \mathrm{~mL} \cdot \mathrm{kg}^{-1} \cdot \mathrm{h}^{-1} \mathrm{CO}_{2}$ (Mitcham et al., 2006), whereas at $5{ }^{\circ} \mathrm{C}$ calculated rates using a $\mathrm{Q}_{10}$ of 4 (Nunes et al., 1995a) range from 12 to $20 \mathrm{~mL} \cdot \mathrm{kg}^{-1} \cdot \mathrm{h}^{-1} \mathrm{CO}_{2}$. For all pallets that showed a linear increase in temperature at their center position, it is possible from the plots of the temperature as a function of time to establish a linear regression and to obtain the corresponding approximate slope. The slopes gave the constant rate of variation of the temperature $\left({ }^{\circ} \mathrm{C}\right)$ as a function of time (minutes) for each pallet. Multiplying the slope by the specific heat of strawberries, which is $4000 \mathrm{~J} \cdot \mathrm{kg}^{-1} \cdot{ }^{\circ} \mathrm{C}^{-1}$ (American Society of Heating, Refrigerating and AirConditioning Engineers, 2006), the rate of heat generation (vital heat) in $\mathrm{J} \cdot \mathrm{min}^{-1} \cdot \mathrm{kg}^{-1}$ is obtained. Once that rate of heat generation is transformed in $\mathrm{kcal} \cdot \mathrm{kg}^{-1} \cdot \mathrm{d}^{-1}$, the respiration rate can be obtained directly using the conversion of $1 \mathrm{mg} \cdot \mathrm{kg}^{-1} \cdot \mathrm{h}^{-1} \mathrm{CO}_{2}$ for every $0.00255 \mathrm{kcal} \cdot \mathrm{kg}^{-1} \cdot \mathrm{h}^{-1}[61.2$ $\mathrm{kcal} / 1000 \mathrm{~kg}$ per $24 \mathrm{~h}$ (Kader, 2002)]. The final respiration rate in $\mathrm{mL} \cdot \mathrm{kg}^{-1} \cdot \mathrm{h}^{-1} \mathrm{CO}_{2}$ was obtained using the density of carbon dioxide at $5{ }^{\circ} \mathrm{C}$ $\left[1.93 \mathrm{mg} \cdot \mathrm{mL}^{-1}\right.$ (calculated from the ideal gas law at standard atmospheric pressure)]. The density at $5{ }^{\circ} \mathrm{C}$ was judged to be a good estimate for the temperature range encountered during the transport operation; the density of carbon dioxide varies only by $\approx 3 \%$ between 0 and $10{ }^{\circ} \mathrm{C}$. In this study, the calculated respiration rates (Table 3) seemed, therefore, to be lower when compared with the data previously published by others. A likely explanation is that the MA pallet shroud system lowered the respiration rates of the fruit compared with the published rates for respiration of strawberries in air. The strong linearity of the temperature curves is shown by the high linear correlation coefficients (Table 3). This agrees with the physics behind our suggestion that the heat of respiration and not the heat from the outside environment caused the increase of temperature, as it is suggested by the company supplying the MAP service (TransFresh Corp., 2004). On the basis of the physics and the MAP system used in this study, our explanation should not, therefore, be discounted, but a more complete study would have been required to confirm this assumption and to evaluate in detail the effect of the MA pallet shroud system on the respiration rate of the fruit.

At this point, it is likely that removing the MAP system will increase the convective heat transfer within the load and potentially mitigate or eliminate the increases in temperature observed during these test shipments. However, this would also eliminate other beneficial effects associated with the use of the MAP system.

Strawberry Weight Loss. Pallets were exposed to similar RH conditions (i.e., near saturation) in the cooling facility in California and the DC in Florida. During transport, the individual clamshells and the MA pallet shrouds system also provided RH conditions close to saturation, which might have contributed to the low fruit weight loss observed (Table 4). In fact, weight loss of strawberry upon arrival at the DC in Florida $(0.5 \%$ to $4.4 \%$ ) was below the maximum $6 \%$ weight loss suggested by Robinson et al. (1975) as the limit before strawberry is considered unacceptable for sale. However, a significant difference was observed between weight loss of fruit from pallets $\mathrm{P}$ and $\mathrm{T}$ (Table 4). For $\mathrm{P}$ pallets, weight loss ranged from $2.0 \%$ to $4.4 \%$, whereas for the T pallets
Table 3. Calculated respiration rates $^{\mathrm{z}}$ during transport for strawberries located at the center of the pallets and corresponding linear correlation coefficients for observed temperature increases versus time.

\begin{tabular}{lcc}
\hline Pallet & $\begin{array}{c}\text { Respiration rate } \\
\left(\mathbf{m L} \cdot \mathbf{k g}^{-1} \cdot \mathbf{h}^{-1} \mathbf{C O}_{2}\right)^{\mathbf{y}}\end{array}$ & $\boldsymbol{r}$ \\
\hline $\mathrm{Tl}(\mathbf{1})^{\mathrm{x}}$ & 5.4 & 0.987 \\
$\mathrm{Pl}(9)$ & 6.1 & 0.991 \\
$\mathrm{P} 2(10)$ & 8.2 & 0.995 \\
$\mathrm{Tl}(11)$ & 7.2 & 0.992 \\
$\mathrm{Tl}(12)$ & 4.4 & 0.982 \\
$\mathrm{P} 3(13)$ & 7.5 & 0.990 \\
$\mathrm{P} 4(14)$ & 5.4 & 0.989 \\
$\mathrm{Tl}(15)$ & 11.0 & 0.994 \\
$\mathrm{Tl}(16)$ & 7.5 & 0.992 \\
$\mathrm{P} 5(17)$ & - & - \\
$\mathrm{Tl} 123)$ & 4.7 & 0.979 \\
\hline
\end{tabular}

${ }^{\mathrm{z}}$ Respiration rates were calculated from the slope of the linear regressions for the center temperature as a function of time. Each slope gives a rate of temperature variation in function of time which once multiplied by the specific heat of a strawberry [4000 $\mathrm{J} \cdot \mathrm{kg}^{-1} \cdot{ }^{\circ} \mathrm{C}^{-1}\left(0.9554 \mathrm{Btu} / \mathrm{lb}\right.$ per $\left.{ }^{\circ} \mathrm{F}\right)$ (American Society of Heating, Refrigerating and Air-Conditioning Engineers, 2006)] can be converted in $\mathrm{kcal} \cdot \mathrm{kg}^{-1} \cdot \mathrm{h}^{-1}$. ( $\left.1 \mathrm{~J} \cdot \mathrm{kg}^{-1} \cdot \mathrm{h}^{-1}=2.39 \times 10^{-4} \mathrm{kcal} \cdot \mathrm{kg}^{-1} \cdot \mathrm{h}^{-1}\right)$. The final respiration rates were calculated using the density of carbon dioxide at $5{ }^{\circ} \mathrm{C}\left(41.0{ }^{\circ} \mathrm{F}\right)\left[1.93 \mathrm{mg} \cdot \mathrm{mL}^{-1}\right.$ $\left(6.973 \times 10^{-5} \mathrm{lb} /\right.$ inch $\left.\left.^{3}\right)\right]$ and the fact that $1 \mathrm{mg} \cdot \mathrm{kg}^{-1}$ $\left(10^{-6} \mathrm{lb} / \mathrm{lb}\right)$ carbon dioxide $\left(\mathrm{CO}_{2}\right)$ per hour corresponds to a vital heat of $0.00255 \mathrm{kcal} \cdot \mathrm{kg}^{-1} \cdot \mathrm{h}^{-1}$ (Kader, 2002)

${ }^{y} 1 \mathrm{~mL} \cdot \mathrm{kg}^{-1} \cdot \mathrm{h}^{-1}=0.0277$ inch $^{3} / \mathrm{lb}$ per hour.

"T $x(y)$ and $\mathrm{P} x(y)$, where " $x$ " refers to the precooling treatments and "y" in parentheses refers to the position of the pallet in the refrigerated trailer (Fig. 1): $x=1$ (immediate and complete precooling), $x=2$ (delayed but complete precooling), $x=3$ (immediate but incomplete precooling), $x=4$ (delayed and incomplete precooling), $x=5$ (no precooling nor refrigeration before transport).

weight loss ranged from $0.5 \%$ to $0.8 \%$. Since the $T$ pallets were already in cold storage for $\mathrm{l} \mathrm{d}$ when the initial weight of the fruit was measured, the data seem to indicate that most of the water was lost through transpiration during the time between harvest and the end of precooling. For the two benchmark shipments, the weight loss was measured exactly as for the $\mathrm{T}$ pallets and the results were found to be in the same range (below 0.9\%). Fruit from pallet P5(17), which was not refrigerated before shipment, showed as expected, the highest weight loss compared with fruit from the other pallets. The weight loss for fruit from pallets $\mathrm{P} 2(10)$ and P4(14), for which precooling was delayed by $4 \mathrm{~h}$, was $3.0 \%$ and $3.1 \%$, respectively, whereas weight loss for fruit from pallets $\mathrm{Pl}(9)$ and P3(13), for which precooling was not delayed, was lower $(2.0 \%$ and $2.4 \%$, respectively). 
Table 4. Weight loss of strawberries between harvest and arrival at the distribution center (DC) in FL $(P$ pallets) and between $1 \mathrm{~d}$ after precooling and arrival at the DC in FL ( $\mathrm{T}$ pallets).

\begin{tabular}{lc}
\hline Pallet & Wt loss $(\%)$ \\
\hline $\mathrm{Pl}(9)^{\mathrm{z}}$ & $2.0 \mathrm{c}^{\mathrm{y}}$ \\
$\mathrm{P} 2(10)$ & $3.0 \mathrm{~b}$ \\
$\mathrm{P} 3(13)$ & $2.4 \mathrm{bc}$ \\
$\mathrm{P} 4(14)$ & $3.1 \mathrm{~b}$ \\
P5(17) & $4.4 \mathrm{a}$ \\
Average P pallets & $3.0 \mathrm{~A}^{\mathrm{x}}$ \\
Tl(1) & $0.7 \mathrm{~d}$ \\
Tl(11) & $0.8 \mathrm{~d}$ \\
Tl(12) & $0.8 \mathrm{~d}$ \\
Tl $(15)$ & $0.6 \mathrm{~d}$ \\
Tl $(16)$ & $0.5 \mathrm{~d}$ \\
Tl $(23)$ & $0.5 \mathrm{~d}$ \\
Average T pallets & $0.7 \mathrm{~B}$ \\
\hline
\end{tabular}

${ }^{z} \mathrm{~T} x(y)$ and $\mathrm{P} x(y)$, where " $x$ " refers to the precooling treatments and " $y$ " in parentheses refers to the position of the pallet in the refrigerated trailer (Fig.

1): $x=1$ (immediate and complete precooling), $x=2$ (delayed but complete precooling), $x=3$ (immediate but incomplete precooling), $x=4$ (delayed and incomplete precooling), $x=5$ (no precooling nor refrigeration before transport).

${ }^{y}$ Mean separation in columns by Duncan's multiple range test at $P=0.05$.

${ }^{x}$ Significant differences between pallets (treatments) determined by analysis of variance (F test) at $P=0.05$.

The effect of higher final precooling temperature was not as important as the effect of delayed precooling on the weight loss of strawberry fruit. For example, the difference in fruit weight loss between pallets $\mathrm{Pl}(9)$ and $\mathrm{P3}(\mathrm{13})$, which were precooled without delay to final temperatures of 1.7 and $10{ }^{\circ} \mathrm{C}$, respectively, was $0.4 \%$ (Table 4 ). For pallets $\mathrm{P} 2(10)$ and $\mathrm{P} 4(14)$, which were precooled after a delay of $4 \mathrm{~h}$ to the same final temperatures, the weight loss difference between the pallets was even smaller $(0.1 \%)$ and not significantly different. However, the difference in fruit weight loss between pallets that were immediately precooled vs. those for which precooling was delayed was significantly higher $(0.9 \%)$.

Visual Quality OF STRAWBERRIES UPON ARRIVAL TO THE COOLING FACILITY, AT THE DC, AND DURING SIMULATED RETAIL DISPLAY. Visual observations of freshly harvested strawberries upon arrival at the cooling facility showed that a large proportion of the fruit was bruised (data not shown). Most of the bruises detected on those fruit were caused by overfilling the clamshells. Because the strawberries from pallet P5(17) were not precooled and were exposed to abuse temperatures for $\mathrm{l} \mathrm{d}$ before transport, the quality was assessed as unacceptable for shipping according to the cooling facility's quality control managers in California. At this point, the fruit were still acceptable for immediate sale. Upon arrival at the DC in Florida, dense water condensation was observed in the clamshells from pallet P5(17). Some lighter condensation was also observed in clamshells from other pallets.

At the beginning of the simulated retail display, the overall average visual quality evaluation for all 18 clamshells from each P pallet showed higher the weight loss (Table 4) the lower was the quality. Fruit from pallet $\mathrm{Pl}(9)$, which was immediately precooled to $1.7^{\circ} \mathrm{C}$, had a significantly better quality when compared with fruit from the other pallets. Quality of the fruit from pallets P2(10) and P3(13), for which cooling was delayed for $4 \mathrm{~h}$ and the fruit then cooled to $1.7^{\circ} \mathrm{C}$, or immediately precooled to $10.0{ }^{\circ} \mathrm{C}$, respectively, was not significantly different. Likewise, visual quality of the fruit was not significantly different for pallets P4(14) and P5(17), for which cooling was delayed for $4 \mathrm{~h}$ and the fruit then cooled to $10.0^{\circ} \mathrm{C}$, or not cooled, respectively. The most striking visual difference between fruit from pallet P5(17) and the other pallets was the dry and brownishgreen fruit calyces. Upon arrival at the DC, no decay was observed on fruit from any of the pallets, but a large number of fruit exhibited severe bruise symptoms.

During simulated retail display, visual quality of the strawberries held at $21{ }^{\circ} \mathrm{C}$ deteriorated very rapidly, regardless of the precooling procedure used (Fig. 6). Visual examination of the fruit showed that decay (primarily gray mold incited by Botrytis cinerea) developed after only $1 \mathrm{~d}$ in samples from all treatments when held at $21{ }^{\circ} \mathrm{C}$. As expected, decay developed initially on the bruised areas of the fruit, spreading afterward to other locations on the fruit surfaces. After $2 \mathrm{~d}$ at $21^{\circ} \mathrm{C}$, almost all of the bruised areas were covered with mycelium and many fruit that had shown slight signs of decay the day before now showed severe decay (i.e., soaked brownish depressions or mycelium growth). After $3 \mathrm{~d}$, the fruit from pallet P5(17) was considered to be unacceptable for sale because of over ripeness, shriveling, leaky fruit, and decay (i.e., visual ratings $<2.0$ ). The dense condensation observed in some of the clamshells at the DC probably contributed to acceleration of the development of decay, particularly on fruit that had been bruised in the field or during packing.

After $1 \mathrm{~d}$ at $21^{\circ} \mathrm{C}, 100 \%$ of the evaluated clamshells from pallet P5(17), that was not precooled, were considered unmarketable, whereas $86.7 \%$ of the clamshells from all the other combined pallets were considered unmarketable after $2 \mathrm{~d}$, and $100 \%$ of those fruit were unmarketable after $3 \mathrm{~d}$. Visual quality of fruit stored at 0 or $6{ }^{\circ} \mathrm{C}$ did not change significantly during the first day of simulated retail display (Fig. 6). However, after $3 \mathrm{~d}$ at 0 or $6^{\circ} \mathrm{C}$, all clamshells evaluated from the precooled pallets, $\mathrm{Pl}(9)$, P2(10), P3(13), and P4(14), were still marketable, whereas $66.7 \%$ of the clamshells from not precooled pallet P5(17) were considered unmarketable. Fruit from pallet $\mathrm{Pl}(9)$ (no delay before precooling to $1.7^{\circ} \mathrm{C}$ ) that were held in simulated retail display at $0{ }^{\circ} \mathrm{C}$ maintained the best visual quality during the 3-d display period, compared with the fruit from the other precooled pallets, which showed acceptable to poor visual quality after $3 \mathrm{~d}$ of simulated retail display. Overall, the quality of fruit from pallet $\mathrm{Pl}(9)$ was considered to be the best, followed by pallets P3(13), and then pallets P2(10), P4(14), and P5(17), which showed the lowest quality rating.

\section{Conclusions}

Results obtained from this study highlight the importance of prompt precooling and the use of optimum storage temperature (i.e., $0^{\circ} \mathrm{C}$ ) throughout the distribution chain and during retail display of strawberries. Temperature profiles during transport showed that the fruit temperatures measured at locations 1 and 23 (i.e., the front and rear of the trailer) in a shipping load were the lowest among all of the instrumented pallets, and therefore, the most likely to maintain excellent strawberry quality throughout shipping. The temperature profiles during transport also showed that a pallet loaded warm into a refrigerated trailer does not seem to affect the temperature 

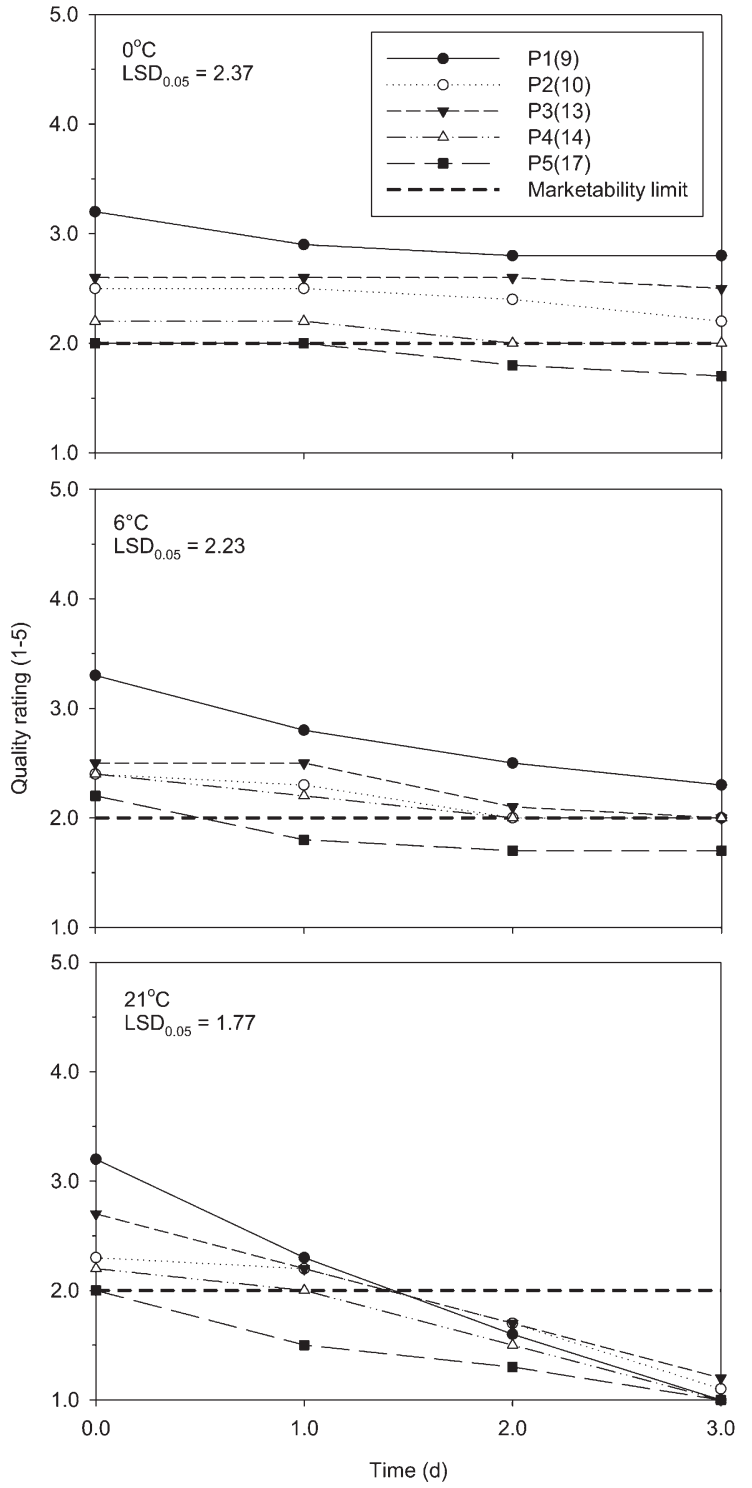

Fig. 6. Average strawberry visual quality during simulated retail conditions $[0,6$, and $21{ }^{\circ} \mathrm{C}\left(32.0,42.8\right.$, and $\left.\left.69.8{ }^{\circ} \mathrm{F}\right)\right] ; 5$ = very good (freshly harvested fruit, firm, turgid), 4 = good (firm fruit with small bruises), 3 = fair (fruit with minor signs of softness, shriveling, bruises), 2 = poor (soft fruit, bruised, overripe, wilted and dry calyces, decay), 1 = very poor (extremely overripe fruit, extremely wilted and dry calyces, leaky and rotten fruit). For P $x(y)$, " $x$ " refers to the precooling treatments and " $y$ " in parentheses refers to the position of the pallet in the refrigerated trailer (Fig. 1); $x=1$ (immediate and complete precooling), $x=2$ (delayed but complete precooling), $x=3$ (immediate but incomplete precooling), $x=4$ (delayed and incomplete precooling), $x=\mathbf{5}$ (no precooling or refrigeration before transport). $\mathrm{LSD}_{0.05}$ corresponds to a least significant difference at $\mathbf{5 \%}$ level of significance.

of the colder adjacent pallets (with MA pallet shrouds).

Data collected upon arrival of the load of strawberries at the DC showed that most of the moisture from the fruit was lost before precooling. Furthermore, fruit water loss was greater when precooling was delayed than when precooling was incomplete, whereas nonprecooled strawberries had significantly greater water loss than fully or partially precooled fruit. Consequently, fruit from the non-precooled treatment would have been rejected at the shipping point, only $\mathrm{l} \mathrm{d}$ after harvest; as corroborated by the cooling facility's quality control managers.

Besides water loss, the most important cause of quality deterioration was found to be overfilling the clamshells. Overfilling was observed to cause excessive bruising of the fruit, which accelerates the development of decay during subsequent handling.

Further research in this area should focus on the quality of the fruit and the economic impact at the retail level when strawberries are shipped without MA pallet shrouds; evaluate the economic aspect of complete precooling vs. partial precooling or no precooling; and evaluate the effect of mechanical damage during field packing on the quality and economic impact at the retail level.

\section{Literature cited}

American Society of Heating, Refrigerating and Air-Conditioning Engineers. 2006. Thermal properties of foods, p. 9.1-9.31. In: 2006 ASHRAE Handbook Refrigeration, Amer. Soc. Heating, Refrigerating Air-Conditioning Eng., Atlanta.

Baird, C.D. and J.J. Gaffney. 1976. A numerical procedure for calculating heat transfer in bulk loads of fruits or vegetables. Amer. Soc. Heating, Refrigerating Air-Conditioning Eng. Trans. 82:525540 .

El-Kazzaz, M.K., N.F. Sommer, and R.J. Fortlage. 1983. Effect of different atmospheres on postharvest decay and quality of fresh strawberries. Phytopathology 73:282-285.

Harker, F.R., H.J. Elgar, C.B. Watkins, P.J. Jackson, and I.C. Hallett. 2000. Physical and mechanical changes in strawberry fruit after high carbon dioxide treatments. Postharvest Biol. Technol. 19:139-146.

Harvey, J.M. 1982. $\mathrm{CO}_{2}$ atmospheres for truck shipments of strawberries, $\mathrm{p}$. 359-65. In: D.G. Richardson and M. Meheriuk (eds.). Symposium Series No.1. Controlled atmospheres for storage and transport of perishables agricultural commodities. Timber Press, Beaverton, OR.

Harvey, J.M., C.M. Harris, W.J. Tietjen, and T. Serio. 1980. Quality maintenance of truck shipments of California strawberries. U.S. Dept. Agr., Sci. Edu. Admin., Adv. Agr. Technol. AAt-W-12/ July.

Kader, A.A. 2002. Postharvest biology and technology: An overview, p. 39-47. In: A.A. Kader (ed.). Postharvest technology of horticultural crops. 3rd ed. Univ. California, Agr. Natural Resources, Publ. 3311.

LeBlanc, D.I. and K.P.C. Hui. 2005. Land transportation of fresh fruits and vegetables: An update. Stewart Postharvest Rev. 1:1-13. 
LeBlanc, D.I., R. Stark, B. MacNeil, B. Goguen, and C. Beaulieu. 1996. Perishable food temperatures in retail stores. New developments in refrigeration for food safety and quality, p. 42-51. Refrigeration Sci. Technol. Proc., Intl. Inst. Refrigeration, Commission C2 with B2, $\mathrm{D} 1$, and D2-3. Lexington, $\mathrm{KY}$.

Mitcham, E.J., C.H. Crisosto, and A.A. Kader. 2006. Strawberry: Recommendations for Maintaining Postharvest Quality. 26 Apr. 2011. <http://postharvest. ucdavis.edu/Produce/ProduceFacts/Fruit/ strawberry. shtml>.

Mitchell, F.G., E.J. Mitcham, J.F. Thompson, and N. Welch. 1996. Handling strawberries for fresh market. Univ. California, Div. Agr. Natural Resources, Publ. 2442.

Nunes, M.C.N., J.K. Brecht, A.M.M.B. Morais, and S.A. Sargent. 1995a. Physical and chemical quality characteristics of strawberries after storage are reduced by a short delay to cooling. Postharvest Biol. Technol. 6:17-28.

Nunes, M.C.N., J.K. Brecht, S.A. Sargent, and A.M.M.B. Morais. 1995b. Effects of delays to cooling and wrapping on strawberry quality (cv. Sweet Charlie). Food Contr. 6:323-328.

Nunes, M.C.N., J.P. Emond, and J.K. Brecht. 2003. Quality of strawberries as affected by temperature abuse during ground, in-flight and retail handling operations. Acta Hort. 604:239-246.

Nunes, M.C.N., J.P. Emond, M. Rauth, S. Dea, and K.V. Chau. 2008. Environmental conditions encountered during typical retail display affect fruit and vegetable quality and amount of waste. Postharvest Biol. Technol. 51:232-241.
Pelayo, C., S.E. Ebeler, and A.A. Kader. 2003. Postharvest life and flavor quality of three strawberry cultivars kept at $5{ }^{\circ} \mathrm{C}$ in air or air $+20 \mathrm{kPa} \mathrm{CO}_{2}$. Postharvest Biol. Technol. 27:171-183.

Robinson, J.E., K.M. Browne, and W.G. Burton. 1975. Storage characteristics of some vegetables and soft fruits. Ann. Appl. Biol. 81:399-408.

TransFresh Corp. 2004. Solving the Problem of in Transit Warming. 26 Apr. 2011. <http://www.transfresh.com/resources/ research-library/04-05-01/solving-theproblem-of-in-transit-warming.aspx $>$.

Villeneuve, S. 1999. Étude des paramètres affectant les performances des comptoirs réfrigérés destinés à la vente au détail des fruits et légumes frais, Masters Thesis, Universite Laval, Québec, QC, Canada. 